\title{
EFFECTS OF THE ORGANIZATIONAL FACTORS ON TEACHERS' RETENTION: PERCEPTIONS OF PRIVATE SECONDARY SCHOOL TEACHERS OF LYARI TOWN
}

\author{
Lubna Oad \\ Lecturer, \\ Department of Education, Benazir Bhutto Shaheed University Lyari, \\ Sindh, Pakistan \\ Email: lubnaparas@gmail.com

\section{Safia Niazi} \\ Assistant Professor, \\ Department of Education, Benazir Bhutto Shaheed University Lyari, \\ Sindh, Pakistan \\ Email: dr.safianiazi@gmail.com
}

\begin{abstract}
The teaching occupation and the essential tasks and duties of teachers are necessary for developing every nation's human resources. The teachers are the pillar of our country, and without them, the standard of our education will suffer since teachers are the nearest to the human mind and are prime drivers of economic development. Therefore, educational administration and organizational factors play a pivotal role in making teachers motivated and satisfied to sustain their academic institutions' jobs and should focus on switching jobs frequently. This study examined the association between organizational and teacher retention in eight private secondary schools in Lyari town Karachi, Sindh Pakistan. The study formulated three objectives and hypotheses. The research design was a correlation-the population of the study comprised of teachers from schools. A random sampling technique was used, and a questionnaire was distributed among 200 teachers to collect data. Data were gathered using an instrument that was self-made with the help of literature reviewed and experts' suggestions. The questionnaire was validated and piloted. The Cronbach Alpha coefficient was determined. Ensure the reliability at 0.85 , respectively. The Pearson correlation statistic was used to test the hypotheses. The findings reveal significant relationships between teachers' salary packages, teachers' workload, professional development opportunities, and teachers' retention in schools. Further, the study's findings reveal that educational administration and management align with government compensation policies regarding teachers' salaries and promotions and focus on their teaching workload and other fringe benefits.
\end{abstract}




\section{KEYWORDS}

Teachers' Retention, Teaching Workload, Professional Development, Secondary private Schools

\section{INTRODUCTION}

Organization in different productions face new challenges in recruiting and retaining the right talents to enhance growth. Growth means strength, and the force required quality performance of concerned people so that the economic downturns will not affect the turnover of any organization. The proper determination of the pertinent organizational and employment factors has the courage to provide overall functional occupational benefits individually and collectively. The process of earning required instinctive talent from teachers and students. School organization can boost progress through different mediations and actions. According to this perspective, educational organizations should accomplish their goals by adopting transformative policies that affect the consistency, timeliness and adequacy of teacher commitment to their learning (e.g., analyzing the demands of school tasks, planning and allocating resources to meet these demands). Teachers' accomplishments are influenced by their efforts, as well as their natural abilities. "Ensuring academic success targets and, in exchange, its efforts, play an essential role in school organizations and teachers."

Teachers are the most valuable assets that schools can't afford to waste. The success of an educational system primarily depends on its instructors' skill and the quality of teachers. Furthermore, no educational objective can be reached without skillful and qualified teachers. Optimum productivity depends upon teachers immediate need satisfaction at the workplace. For teachers to be more effective, they need to be satisfied and happy in their intuitions. The educational administration's responsibility is to fulfil their teachers' needs accordingly (Agboola \& Offong, 2018).

Teachers are the most relevant and essential elements of today's education system, regardless of the environment. The strength of the education system relies primarily on the efficiency and quantity of its students. Moreover, no educational goal for any country's growth will ever be accomplished without a sufficiently trained and inspired teaching team. Consequently, for teachers to achieve maximum efficiency, their satisfaction and happiness are most important in the workplace (Agboola \& Offong, 2018). A school aims to employ trained and dedicated teachers to provide a better education for its pupils to get a high education quality. Thus, schools must maintain professional teachers. When teachers leave the field or become unhappy, it harms pupils and the school's progress. To ensure consistent education delivery, it is essential that consistently retain highly trained teachers in the school system. Teacher retention is one of the most common and crucial factors for schools, and educational administrators are responsible for running the schools' education system. They focus 
on teachers' retention by giving them intensives, rewards and encouragement to motivate the teachers. However, retaining effective teachers is essential to the discipline's sustainability; teachers are ensuring continuity of the discipline; teachers leave the field leading to uncertainty, program closures reduced opportunities for the students and limited learning resources (Lawver et al., 2018; Rinke, 2007).

Existing research suggests that between $30-50 \%$ of teachers will leave the profession within the first five years of employment (Blackburn et al., 2017; Hughes et al., 2015; Rinke, 2007). Teachers are not entirely happy with their work in Pakistan and abroad. The academic quality and student motivation standards have been adversely affected (Amin et al., 2017). A survey shows about 27,037 teachers at public and private schools in Karachi and that the average monthly salary is Rs 14,000.

The teachers are not satisfied with poor working resources, teaching-learning materials, teaching heavy workload, lack of autonomy, clerkly work, salary packages and professional development opportunities and environment of schools. Because of this, they are seeking to get a new chance to move from one school to another school in a short period of the job. Teachers' high levels of frustration contribute to high turnover, high absenteeism and attrition (Bashir, 2017). (Bashir, 2017). According to Farinde-Wu \& Fitchett (2018), teacher turnover negatively affects student success and achievement and depletes school and district resources for recruiting, hiring, and educating new teachers.

Organizations see their workers as a key component of their firm and an advantage that will help them increase their overall organizational efficiency and profitability (Moser \& McKim, 2020; Kanyurhi \& Akonkwa, 2016). The majority of research is done on the various factors that affect an employee's success. However, it was discovered that relatively few studies had been conducted on these five variables: salaries packages, teaching workload and professional development opportunities, support of administration (organizational management support), reimbursement, rewards and compensation, and corporate identity in a private school located in an underprivileged area.

Additionally, each of these variables is used in a variety of contexts (Webb, 2018). Furthermore, a few studies have been undertaken in the environment of the schools. It is more emphasizing value and meaning in field research. Teachers are the keystone of every educational system, and their incompetent attitude negatively impacts students' overall academic achievements (Amin et al., 2013; Sharma \& Dhar, 2016). These features are typically considered in various contexts, but these features determine future decisions and influence the efficiency and interpersonal relationship with administrative authorities (Collin \& Brotcorne, 2019; Gigliotti et al., 2019). 
Numerous research studies have been conducted on the above subjects. Nonetheless, few studies on teachers' performance and success using various variables contribute to job satisfaction or dissatisfaction due to their continuing jobs in the same institution. As a result, this study is being undertaken to determine the variables contributing to its implementations resulting in private educational institutions. The purpose of this research is set in the sense of Pakistani context, more specifically in Karachi's private secondary schools.

\section{LITERATURE REVIEW Theoretical background}

Herzberg (1966) says that workers are happy and unhappy when in some situations, which lead to behaviour. These feelings and emotions seem to affect both positively and negatively on their performance and job satisfaction. It induces satisfaction due to these reasons. Factors that the workers feel unhappy with are, however, defined as factors of dissatisfaction. Satisfaction and dissatisfaction factors are the terms for these variables. Recognizing, accountability, development, and success are all factors that contribute to job satisfaction. Happiness is a product of the interaction of these elements (Bolman \& Deal, 2017, Hackman \& Oldham, 1976)

Therefore, satisfaction factors of teachers like salaries, remuneration, psychological safety, teaching workload, positive work environment, professional development opportunities, security make them satisfied or dissatisfied with their jobs and their institutions. Hence, this study provides an essential foundation for examining how organizational factors affect teachers' retention. Because (organizational factors) support of management, salary packages, teaching workload, and professional growth opportunities are the key factors for teachers to remain in the institutions for a long time (Harwood \& Koyama, 2021; Hofstede, Hofstede \& Minkov, 2005; Moser \& McKim, 2020).

\section{Salaries \& remuneration of teachers}

Several scholars have repeatedly discussed the need for teacher remuneration as a key factor in teacher retention. Teacher motives through the good salary packages and remains in same institutions and field of work for a long time. A good salary affects teachers' intention to remain in the teaching profession. Like any other profession, teaching should be considered a profession with a wide variety of teaching grants, such as medical, dental, and vision coverage. High remuneration enhances both the "quality of the skilled teachers and rate of retention". A good amount of pay significantly impacts teachers' inner satisfaction and can also be seen as a criterion for deciding whether or not to work. Various researchers found that their respondents respond, "they will remain on their teaching jobs if the salary is raised and incentives are provided" (Card, 2012; DO, 2020; Shi \& Sicular, 2010). 
Salaries and intensives are among the primary considerations that make the teacher know how to work at school. Compensation and incentives Compensation is one of the fundamental needs a person has to survive and fulfil their life requirements (Bryant \& Allen, 2013). Salaries and incentives are the elements that satisfy the expectations and induce disappointment when they are less than their level (Muguongo et al., 2015). As a result, teachers are happier and satisfied when paid higher wages, which provides satisfaction and creates a positive relationship, and builds confidence with the administration (Gupta et al., 2018; Williams \& Horodnic, 2017). According to Christians et al. (2016), high salaries lead to better employee performance. It also builds confidence and a sense of belonging to the institutions and solidarity among supervisors. As a result, institutions often share their revenues and profits with their employees (Mai et al., 2016).

\section{Teaching workload}

Most educational institutions do not have evident and coherent centralized systems and parameters for allocating academic workload, which considers specific activities related to blended teaching and learning. There is a lack of formally documented evidence that could precisely reflect the workload associated with the blended learning environment. It has also been observed that e teaching and administrative work is a significant factor in teachers' dissatisfaction. The expansion in teacher workload has been observed as an unfavorable outcome of private sector schools in Pakistan. Many researchers found that teachers spent most of their time doing non-teaching duties, which increased workload and anxiety among teachers. It is mainly related to the teachers' exhaustion and their job satisfaction. The heavy workload and depression created self-administering issues as it can be endorsed by the management, in part, to how teachers organize themselves forcefully and struggle badly. The workload can be the cause of dissatisfaction and less motivation for teachers. They cannot involve in the teaching-learning process properly; the transmission of information and knowledge may not lead to achieving educational goals (Bettini, 2018). When complete restructuring is required, these organizing principles are likely to maximize workload by dividing, replicating activity, and adding new moves to those already in place (Wood, 2019).

The workload is one of the primary causes that demotivates most workers in organizations and institutions. It is also expected that teachers will gradually become overwhelmed with work and tension due to repetitive activities (Silva et al., 2020; Warm et al., 2018). It would affect their mental health and overall success, causing students to suffer in education (Abbas \& Iqbal, 2020; Durrani, 2019). The school administration is also still doing its hardest to consider the importance and sensitiveness to the workload of its teachers. The workload does not only make the teachers stressed and depressed but also affect the students' learning and school 
environment (Van Acker et al., 2018). A lack of school teachers, or some other vital service sector employee, presents an unsettling problem that raises several issues for the administration and forces them to make quick decisions (Bettini et al., 2018). These decisions are often favourable to the school administration, but they are challenging to manage (Driessen, 2020; Suber et al., 2019).

\section{Professional development opportunities}

The core demand of $21^{\text {st }}$-century education is to develop critical thinking and problemsolving abilities in teachers and students. To create these skills, there is a need to build variety in teaching style. In addition, active learning approaches also address the growth of problem-solving skills.

There are various pedagogical methods, such as brainstorming and group work, collective and cooperative instruction and seminars, workshops and team-based problem-solving responsibilities; these teaching techniques are also motivated by emphasizing the importance of equipping teachers with the expertise and characteristics to become self-directed and highly independent long-lasting. Teachers should use effective teaching-learning methods to build these keys 21 st-century skills in their classroom. Teachers with proper experience and a strong pedagogical background were found to be more effective in their teaching-learning process and their teaching career.

As a result, the existence of a strong association between teacher professional development and instructional methods has been established. The essential resources are teachers and important positions in the service sector (Prakasch \& Ghaya,2019). In addition, it is impossible to neglect the value of teachers' retention, commitment and job satisfaction. Therefore, organizations like schools require them to make some efforts for their teachers to focus on their career development so that they are motivated to improve their performance and committed towards the institutions (Cheon et al., 2018).

Training is essential to provide teachers with new skills, experience and learning. Training for new and old workers is successful because they have unique expertise, strategies and pedagogy (Coldwell, 2017; Durrani, 2019). Training, workshops and seminars are also an integral aspect for assessing the school's overall performance, recognizing the shortcomings in the various fields, and continuously tracking them properly. Additionally, pieces of training are needed to indulge learners and reflect on the learning outcomes of those sessions of training (Krasnova \& Shurygin, 2020). Development is also an integral component of an institution and can improve all its job activities and improve eagerness among teachers or employee (McKim \& Velez, 2017; Msuya, 2016.). 
Succession planning is a crucial factor that HR departments always consider while planning for its future (Nadim et al., 2012). Likewise, teachers who are confident, trained, and inspired enough to take on additional duties with their regular teaching tasks are often expected to be encouraged in schools to a better place (Fletcher-Wood $\&$ Zuccollo, 2020). The training and development are classified into two categories 1 . Human development level 2. Administration at the local level (Jones \& Watson, 2017). Human growth degree means combining training and development at all levels of management, technology and education, improved planning capabilities, selfsufficient community construction, local workforce development, modernization and innovative skills development (Milne, 2020).

\section{Conceptual framework of the study}

Figure 1 represents the conceptual framework of the study, which is driven by the literature. In this framework, the Organizational role is the independent variable (Salaries, teaching workload and Professional Development Opportunities), and teachers' retention depends on the study's dependent variables.

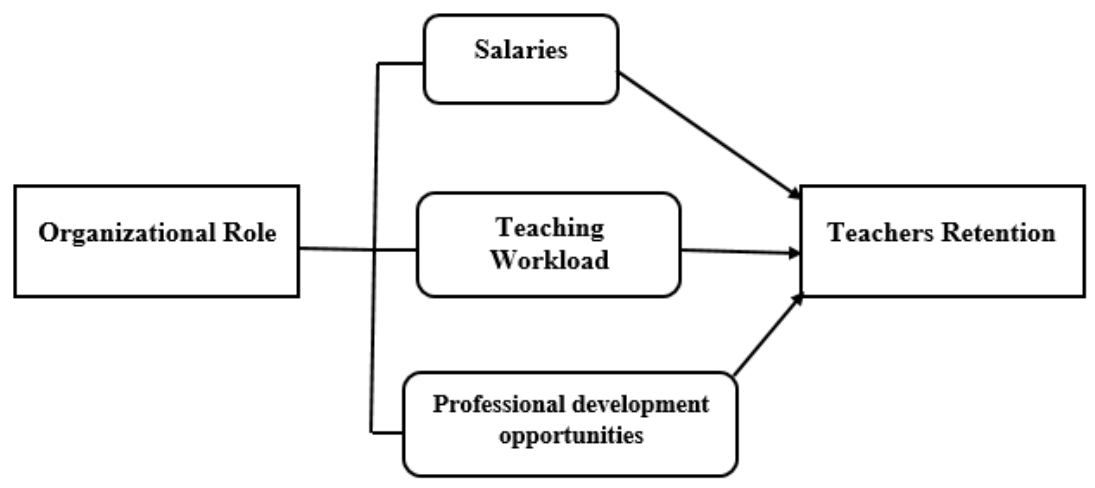

Figure1. Conceptual framework of the study

\section{RESEARCH OBJECTIVES}

1. To find out the relationship between teacher retention and salaries of teachers.

2. To determine the relationship between teacher retention and the teaching workload of teachers.

3. To investigate the relationship between teacher retention and professional development opportunities of the teachers.

4. To explore the importance of organizational factors in the development of the learning process.

\section{RESEARCH HYPOTHESES}

1. There is no significant relationship between salaries and teacher retention. 
2. There is no significant relationship between teaching workload and teachers' retention.

3. There is no significant relationship between professional development opportunities and teachers' retention.

\section{RESEARCH METHODOLOGY}

This research study incorporated a correlational design used to discover relationships between variables (Caruth, 2013). The population of the study comprised teachers from eight private secondary schools of Lyari Town, Karachi. The sample size was 200 teachers. The sampling technique employed was the random sampling method. The schools were selected proportionately, and a simple random sampling technique was used to determine teachers based on male and female teachers (Strata). Data were gathered with a self-made instrument after literature reviewed and experts' suggestions. The tool items were subjected to face validity and clarity of language by research experts and were further subjected to predictive validity test using Pearson correlation statistic. The instrument was validated, and pilot testing was done. The reliability of the tool is 0.853 that meet the threshold value of Cronbach. Data were analyzed using the statistical software program and recorded into SPSS Statistics. Tables were generated to reveal findings from the analysis. Due to the variable data's continuous nature, a Pearson product-moment correlation coefficient was performed with a significance level set at a $95 \%$ confidence level $\mathrm{p}<.05$.

\section{DATA ANALYSIS}

\section{Descriptive statistics}

Table 01: Demographic Information

\begin{tabular}{llll}
\hline $\begin{array}{l}\text { Demographic } \\
\text { Variables }\end{array}$ & Categories & Frequency & Percentage\% \\
\hline Gender & Male & 62 & \\
& Female & 138 & $69 \%$ \\
\hline \multirow{3}{*}{ Academic } & Intermediate & 15 & $7.5 \%$ \\
Qualification & Graduation & 118 & $59 \%$ \\
& Masters & 65 & $32.5 \%$ \\
& M.Phil. & 2 & $1 \%$ \\
\hline Field & Arts & 74 & $35.9 \%$ \\
& Science & 64 & $31.1 \%$ \\
& Commerce & 62 & $30.1 \%$ \\
\hline Experience & $0-02$ & 100 & $50 \%$ \\
& $03-04$ & 69 & $34.5 \%$ \\
& $05-06$ & 31 & $15.5 \%$ \\
\hline
\end{tabular}




\begin{tabular}{llll}
\hline & 20 students & 19 & $9.5 \%$ \\
& & 46 & $23 \%$ \\
Enrollment & $20-30$ students & 108 & $54 \%$ \\
in Class & & 27 & $13.5 \%$ \\
& $31-40$ students & \\
& & \\
& above 41 students & \\
\hline
\end{tabular}

Table 01 consists of descriptive statistics (demographic information) of the respondents. The participants' information includes the percentage of male (31\%) and female participants $(69 \%)$. The academic qualification of participants includes intermediates (7.5\%), Graduates (59\%), masters (32.5\%) and M.Phil. (1\%). Participants had degrees in Arts (35.9\%), science $(31.1 \%)$ and commerce $(30.1 \%)$. Experience includes (50\%) participants have (0-02), (34.5\%) participants (03-04), (15.5\%) participants (05-06). The classroom enrollment ratio is 19 teachers have $(9.5 \%)$ students in the class, 46 teachers have $(23 \%)$ in the class, 108 teachers have (54\%) enrollment in the class and 27 teachers having (13.5\%) enrollment in the classroom.

Table 02: Descriptive Statistic of all variables

\begin{tabular}{llll}
\hline Variables & N & Mean & S.D \\
\hline Salaries & 200 & 46.8 & 8.56 \\
Teaching workload & 200 & 89 & 16.7 \\
Retention Rate & 200 & 86.15 & 4.79 \\
Professional & 200 & 75.35 & 14.9 \\
Development & & & \\
Opportunities & & & \\
Total Scale Score & 200 & 89.11 & 16.35 \\
\hline
\end{tabular}

A mostly significant relationship existed among variables. The Pearson-product moment correlation coefficient was calculated, and the mean and standard deviation was found among the variables. Salaries of teachers have $(M=46.8, S D=8.56)$, teaching workload $(\mathrm{M}=89, \mathrm{SD}=16.7)$, retention rate $(\mathrm{M}=86.15, \mathrm{SD}=4.79)$ and professional development opportunities $(\mathrm{M}=75.35, \mathrm{SD}=14.9)$. The teachers' retention is significantly correlated to the good packages of salaries and teaching workload. Still, there is no significant correlation to the professional development opportunities for teachers' career growth.

Table 03: Pearson Correlations Between Occupational Incentive indices and Teacher Retention 


\begin{tabular}{|c|c|c|c|c|}
\hline Variables & 1 & 2 & 3 & 4 \\
\hline 1. Teachers' Retention & - & $.822^{*}$ & $.605^{*}$ & $.704 *$ \\
\hline 2. Salaries & & --- & $.701 *$ & $.622 *$ \\
\hline $\begin{array}{ll}\text { 3. } & \text { Teaching } \\
\text { Workload }\end{array}$ & & & -- & $.603 *$ \\
\hline $\begin{array}{l}\text { 4. Professional } \\
\text { Development } \\
\text { opportunities }\end{array}$ & & & & --- \\
\hline
\end{tabular}

*Correlation is significant at the 0.05 level (2-tailed)

Table 3 shows the correlation between teachers' retention, salaries, teaching workload and professional development opportunities. Analysis of the sample found that Teachers' retention has a strong positive correlation with teachers' salaries $(r=.822)$. It also shows the Strong relationship between Salaries and teaching workload $(r=$ .605). Professional development opportunities and teachers' retention have a moderate relationship $(\mathrm{r}=.704)$. Further, this table shows the strong association of teachers' salaries with teaching workload $(\mathrm{r}=.701)$, and teaching workload has a moderate relationship $(r=.603)$ with professional development opportunities. So we can say that teachers' retention is positively correlated with teachers' salaries, the workload of teaching, and professional development opportunities.

\section{Testing Hypotheses}

H1: There is no significant relationship between salaries and teacher retention.

Table 4: Pearson Correlation Between Professional Development opportunities and teachers' Retention $(N=200)$

\begin{tabular}{lll}
\hline Variables & r & p-values \\
\hline Teachers' Retention (X) & .822 & .000 \\
Salaries (Y) & & \\
\hline
\end{tabular}

Table 3 shows a statistically strong correlation between teachers' retention and salary $(\mathrm{r}=.822)$. It was found that $\mathrm{p}<0.05$, i.e. .000, the null hypothesis is rejected and found a significant relationship between teachers' retention and salary. It means teachers will retain if they have good salary packages in their organization.

H2: There is no significant relationship between teaching workload and teachers' retention. 


\begin{tabular}{|c|c|c|}
\hline Variables & $\mathbf{r}$ & p-values \\
\hline Teachers' Retention (X) & .605 & .000 \\
\hline Teaching workload (Y) & & \\
\hline
\end{tabular}

Table 4 shows the statistically moderate correlation between teachers' retention and workload $(r=.605)$. It was found that $\mathrm{p}<0.05$, i.e. .000 , therefore null hypothesis is rejected that there is a significant relationship between teachers' retention and teaching workload. It means teachers retention depends on teachers' workload; if they have more workload, they will switch the job.

H3: There is no significant relationship between professional development opportunities and teachers' retention.

Table 5: Pearson Correlation Between Professional Development opportunities and teachers' Retention $(N=200)$

\begin{tabular}{lll}
\hline Variables & R & p-values \\
\hline Teachers' Retention (X) & .704 & .055 \\
& & \\
Professional Development & & \\
Opportunities (Y) & & \\
\hline
\end{tabular}

Table 5 shows the correlation between teachers' retention and workload $(\mathrm{r}=.704)$ statistically. It was found that $\mathrm{p}<0.05$, i.e. .055 , the null hypothesis is accepted that there is no significant relationship between teachers' retention and professional development opportunities. It means teachers' retention is not depending on teachers' professional development opportunities. Conversely, teachers are not interested and do not find sufficient opportunities for their career growth. They shall leave the present employer as soon as they find a better alternative, resulting in high turnover intention.

\section{CONCLUSION AND DISCUSSION}

This study reveals that teachers' retention has a substantial and optimistic connection with organizational assistance, salaries and heavy workload. Therefore, in this study, out of four variables. Salaries of teachers and teaching workload showed a positive association with teacher's retention in private schools of Lyari town. It is also suggested by Sorensen (2015) that "organizational factors motivated teachers to do well when during the teaching in the classroom, and they feel comfortable to stay in 
the schools for long". They will not switch their job quickly. Organizational support to increase their overall performance of teachers. According to Tehseen and Hadi (2015), "The support of heads is one of the core elements that lets the institutions build up its relationships with its teachers and build confidence between them that improve the performance of the teachers and their efficiency." According to Tehsen and Hadi (2015).

One of the findings of this article, as a result of the first objective, is that salaries, benefits, rewards, compensation and incentive have a direct association with teacher success and performance. They will be satisfied and stay remain in the institute for a long time. As it was found by McKim \& Velez, (2015), "Teachers sense the need for their colleagues to recognize each other and they are more concerned with positive feedback of their school heads." If salary upturn is 10 to $15 \%$ is has been observed that the performance of teachers also increases 10 to $15 \%$ or above. This has long term benefits for students and school organization as well. Thus, most teachers get unhappy and dissatisfied even earlier if their compensatory expectations are not met (Imazeki, 2005; Tulenan, 2015).

The result of the second objective illustrated the significant positive connection between teachers' retention (hold on) and the workload of the teachers. It has been observed that teachers are facing uncontrollable situations of scheduling, administrative duties and non-teaching tasks along with teaching. The lack of helpful resources supports uncomfortable circumstances and enforce psychologically as well a good teacher to quit. There is a need to establish a manageable workload keeping only the essentials to cope up with the lack of flexibility to be active in professional learning. Moreover, as workers evaluate task-based jobs, the workload has a negligible effect on efficiency (Abbas \& Iqbal, 2020).

The result of the third objective show professional development opportunities are not significantly related to the teachers' retention. The teacher is very buy in routine work and responsibilities including taking classes, assessment, maintaining reports and recording every pupil's progress. Teachers are only motivated with good salaries and don't want to take a heavy workload to make them depressed during their job. They usually bound to attend the straining even on-off timings or on holidays. Due to this, detachment from work and personal life will occur, loss of enjoyment and feeling of isolation rise and they feel mental pressure, as a result, teachers leave. Teachers are not authorized sometimes to modify the course outline. They are the ones who teach students but mostly they are ignorant people in this task. When their contribution in making syllabus do not consider valuable they feel stranger and isolated. "Hence, the teachers again feel demotivated to improve teaching skills and their students remain jammed in the same level of performance. So the process needs to be changed to make 
the training longer impactful (Dodero et al.,2017).” According to Kumar and Jauhari (2016), the employees are very much aware of their needs. Therefore, they do not show loyalty unless the organization shows commitment towards positively influencing and facilitating them.

We are now in the $21^{\text {st }}$ century and it brings numerous challenges in every field of life. Like any other occupation teaching also need moderation and modification to cope up with emerging issues and challenges. In this regard teachers of the present era working hard and trying to tackle all the confronts bravely and passionately. This cause demands a raise in teacher's salary packages to deal with retention because they are nowadays operating multiple screens, various computer-generated programs and manifestos. Some communities are behind teacher raises $100 \%$, while others feel that teachers are being paid by their tax to "sit at home" right now. In the past, it has been observed on both the federal and provincial level that education and educators are not a top priority when it comes to funding. But, teachers continue to show up and teach students sincerely. In the present era of covid-19 the home life of teachers suffered a lot, their families have taken a backseat as teachers trying to give their students the best possible instructions. It is, therefore, a time to raise their salaries and value their time to avoid retention.

The statistics applied in this study is correlation testing. In future, the causes and effects and impact of the best leadership style of administrator can become good variables. The overall conclusion deliberates that employee of every educational organization expect fairly and consistent dealing, ensuring career enrichment opportunities and economic reward to promote productive professional performance. The sample size of this study is small, further research may increase the sample size to get more comprehensive and effective results. This research focuses on the sample selected from private secondary schools of Karachi. Upcoming surveys can bring a selection from the population of different cities and the public sector as well. Future researchers can also contribute by exploring more factors such as the pros and cons of teaching to improve the teachers' turnover at various educational levels.

Moreover, a parallel study may also be conducted on the formulation of strategic planning about an interactive process of goal setting, communication, observation and evaluation to support retain and development exceptional teachers to bring positive change and success in educational institutes. There is a need for formulation and implementation of a good performance management system as well to serve organizational maintenance and enable teachers to learn about their performance against organization expectation. Further research on the topic of the best manageable strategy regarding personal and professional life circumstances of teacher educators will also contribute to the field of education. 


\section{RECOMMENDATIONS}

Regardless of the study's limitation, the study's result and finding suggest that school administration and human resource department, (such as facilitators, coordinators, vice-principal, and principals) must provide all necessary support to their teaching staff by formulating well-being strategy to invest in teachers need to reduce stress and extra burden to achieve the best output in the form of students' progress.

One-off the tough phase of teaching is that they have a short period to prepare for the next level. A person does best when there is a time and scope off things, it causes several time mental stress. There is a need to make a policy to deal with a short time duration. There must be a need for a healthy environment and good communication between both sides, to share vision and decisions for ensuring that a teaching staff also has empowerment in all valuable decision-making process. It will help them to reveal their valid grievances and ambiguity with the administration.

"Compensations should be up to the mark, and their policies must be revisited times after times to get the best potential out of teachers (Smith et al., 2019)." It is also suggested that if the administration wants to avoid the challenge of teacher's retention they should arrange workshops and pieces of training, based on time management skills so that their teaching staff perceive their reflection on professional learning more constructively rather than stressfully. There is also a requirement of preparing ACR (annual confidential report) or appraisal report in the private sector as well as the public sector to announce feedback about the performance of teachers to encourage them with incentives and rewards to motivate them.

The average teachers work hours comprised of nine to ten hours. It will cause many burnouts like the sense of self-doubt, trapped, unsocial stressful life and escalation of dissatisfaction. Stakeholders and policymakers should take an initiative to provide satisfactory resources and activities which helps teachers to deal with all the abovementioned problems smartly.

Teacher pay has been in headlines across the world, it is also recommended that salary policies should be made by policymakers for private school teachers through collective bargaining between teachers' unions and school districts officers to set a salary package and guidance so that the pay scale according to teachers' abilities and nature of work and requirements can be formulated. When policymakers and stakeholders set the salary packages for their teachers, the teachers can have the access to check that institutional policy before applying to work at a private school. This will help teachers to prepare their mind accordingly and the risk of teacher retention will be under control. 
School administration should undertake decisions and form a strategy to analyze the workload and tasks associated with the integration of non-teaching work, practices of digital education and technologies while teaching. There is also a requirement of a personnel plan including clear engagement strategies for staff change management that are familiar to learn new techniques which help to understand the multidimensional impact on training and pedagogy.

\section{REFERENCES}

Abbas, M., \& Iqbal, R. (2020). Impact of Job Satisfaction on Employee Turnover Intents: Evidence from Private Universities in Karachi, Pakistan. RADS Journal of Business Management, 2(1), 48-58.

Abbas, M., \& Iqbal, R. (2020). Impact of Job Satisfaction on Employee Turnover Intents: Evidence from Private Universities in Karachi, Pakistan. RADS Journal of Business Management, 2(1), 48-58.

Agboola, B., \& Offong, D. E. (2018). Occupational Incentives and Teacher Retention in Private Secondary Schools in Akwa Ibom State, Nigeria. Journal of Teacher Education and Educators, 7(3), 263-277.

Amin Afshar, M., \& Mojavezi, A. (2017). The Effect of Aural and Visual Storytelling on Vocabulary Retention of Iranian EFL Learners. English Language Teaching, 10(4), 92-99.

Amin, M., ullah Shah, R., Ayaz, M., \& Atta, M. A. (2013). Teachers Job Performance at Secondary Level in Khyber Pakhyunkhaw, Pakistan. Gomal University Journal of Research, 29(2), 100-104.

Bashir, L. (2017). Job satisfaction of teachers in relation to professional commitment. The International Journal of Indian Psychology, 4(4), 52-59.

Bettini, E. A., Jones, N. D., Brownell, M. T., Conroy, M. A., \& Leite, W. L. (2018). Relationships between novice teachers' social resources and workload manageability. The Journal of Special Education, 52(2), 113-126.

Blackburn, J. J., Bunch, J. C., \& Haynes, J. C. (2017). Assessing the relationship of teacher selfefficacy, job satisfaction, and perception of work-life balance of Louisiana agriculture teachers. Journal of Agricultural Education, 58(1), 14-35. https://doi.org/10.5032/jae.2017.01014.

Bolman, L. G., \& Deal, T. E. (2017). Reframing organizations. San Francisco, CA: JosseyBass.

Bryant, P. C., \& Allen, D. G. (2013). Compensation, benefits and employee turnover: HR strategies for retaining top talent. Compensation \& Benefits Review, 45(3), 171-175.

Card, D., Mas, A., Moretti, E., \& Saez, E. (2012). Inequality at work: The effect of peer salaries on job satisfaction. American Economic Review, 102(6), 2981-3003.

Caruth, G. D. (2013). Demystifying mixed methods research design: A review of the literature. Online Submission, 3(2), 112-122.

Cheon, S. H., Reeve, J., Lee, Y., \& Lee, J. W. (2018). Why autonomy-supportive interventions work: Explaining the professional development of teachers' motivating style. 
Teaching and Teacher Education, 69, 43-51.

Christians, N. E., Patton, A. J., \& Law, Q. D. (2016). Fundamentals of turfgrass management. John Wiley \& Sons. Cohen, E. (2017). Employee training and development. In CSR for HR (pp. 153-162). Routledge

Coldwell, M. (2017). Exploring the influence of professional development on teacher careers: A path model approach. Teaching and Teacher Education, 61(1), 189-198. https://doi.org/10.1016/j.tate.2016.10.015.

Collin, S., \& Brotcorne, P. (2019). Capturing digital (in) equity in teaching and learning: A sociocritical approach. The International Journal of Information and Learning Technology.

Day, N. E. (2016). Compensation: Total Rewards Programs in Nonprofit Organizations. The Jossey-Bass Handbook of Nonprofit Leadership and Management, 639-687.

DO, T. T. (2020). Critical Factors Affecting the Salaries of Employees of Manufacturing Enterprises in Vietnam. The Journal of Asian Finance, Economics, and Business, 7(6), 485-494.

Dodero, J. M., Mota, J. M., \& Ruiz-Rube, I. (2017, October). Bringing computational thinking to teachers' training: a workshop review. In Proceedings of the 5th International Conference on Technological Ecosystems for Enhancing Multiculturality (pp. 1-6).

Driessen, E. A. M. (2020). Parental influence on students' stress (Master's thesis).

Durrani, T. I. K. (2019). Factors Affecting Teacher's Performance: Evidence from Private Secondary Schools of Karachi. RADS Journal of Business Management, 1 (2), 67-77.

Durrani, T. I. K. (2019). Factors Affecting Teacher's Performance: Evidence from Private Secondary Schools of Karachi. RADS Journal of Business Management, 1 (2), 67-77.

Farinde-Wu, A., \& Fitchett, P. G. (2018). Searching for satisfaction: Black female teachers' workplace climate and job satisfaction. Urban Education, 53(1), 86-112.

Fletcher-Wood, H., \& Zuccollo, J. (2020). The effects of high-quality professional development on teachers and students: A rapid review and meta-analysis. Education Policy Institute.

Gigliotti, R., Vardaman, J., Marshall, D. R., \& Gonzalez, K. (2019). The role of perceived organizational support in individual change readiness. Journal of Change Management, 19(2), 86-100.

Gopinath, R., Yadav, A., Saurabh, S., \& Swami, A. (2020). Influence of Job Satisfaction and Job Involvement of Academicians with special reference to Tamil Nadu Universities. International Journal of Psychosocial Rehabilitation, 24(3), 4296-4306.

Gupta, P., Goldman, T., Hernandez, E., \& Rose, M. (2018). Paid family and medical leave is critical for low-wage workers and their families. Center for Law and Social Policy. Retrieved from: https://www. clasp. org/publications/fact-sheet/paid-family-andmedical-leave-critical-low-wageworkers-and-their-families.

Hackman, J. R., \& Oldham, G. R. (1976). Motivation through the design of work: Test of a theory. Organizational behavior and human performance, 16(2), 250-279.).

Harwood, C., \& Koyama, D. (2021). Employing reflective practice to inform adjunct-faculty onboarding. Innovation in Language Learning and Teaching, 1-13.

Herzberg, F. I. (1966). Work and the nature of man.

Hofstede, G., Hofstede, G. J., \& Minkov, M. (2005). Cultures and organizations: Software of the mind (Vol. 2). New York: Mcgraw-hill. 
Hughes, A., Matt, J., \& O'Reilly, F. (2015). Principal support is imperative to the retention of teachers in hard-to-staff schools. Journal of Education and Training Studies, 3(1), 129-134. doi:10.11114/jets.v3i1.622

Imazeki, J. (2005). Teacher salaries and teacher attrition. economics of education Review, 24(4), 431-449.

Jones, D., \& Watson, S. B. (2017). The relationship between administrative leadership behaviors and teacher retention in Christian schools. Journal of Research on Christian Education, 26(1), 44-55.

Kanyurhi, E. B., \& Akonkwa, D. B. M. (2016). Internal marketing, employee job satisfaction, and perceived organizational performance in microfinance institutions. International Journal of Bank Marketing pp-1-43.

Krasnova, L. A., \& Shurygin, V. Y. (2020). Blended learning of physics in the context of the professional development of teachers. International Journal of Technology Enhanced Learning, 12(1), 38-52.

Kumar, M., \& Jauhari, H. (2016). Satisfaction of learning, performance, and relatedness needs at work and employees' organizational identification. International Journal of Productivity and Performance Management, 65(6), 760-772.

Lawver, R. G., Foster, D. D, \& Smith, A. R. (2018). Status of the U. S. supply and demand for teachers of agricultural education, 2014-2016. http://aaaeonline.org/Teacher-SupplyandDemand.

Mai, K. M., Ellis, A. P., Christian, J. S., \& Porter, C. O. (2016). Examining the effects of turnover intentions on organizational citizenship behaviors and deviance behaviors: A psychological contract approach. Journal of Applied Psychology, 101(8), 1067.

McKim, A. J., \& Velez, J. J. (2015). Exploring the relationship between self-efficacy and career commitment among early career agriculture teachers. Journal of Agricultural Education, 56(1), 127-140. https://doi.org/10.5032/jae.2015.01127

McKim, A. J., \& Velez, J. J. (2017). Developing self-efficacy: Exploring preservice coursework, student teaching, and professional development experiences. Journal of Agricultural Education, 58(1), 172-185. https://doi.org/10.5032/jae.2017.01172

Milne, D. Y. (2020). Strategies for Increasing Employee Productivity in Small Technology Consulting Businesses.

Moser, E. M., \& McKim, A. J. (2020). Teacher retention: A relational perspective. Journal of Agricultural Education, 61(2), 263-275.

Moser, E. M., \& McKim, A. J. (2020). Teacher retention: A relational perspective. Journal of Agricultural Education, 61(2), 263-275.

Msuya, O. W. (2016). Exploring levels of job satisfaction among teachers in public secondary schools in Tanzania. International Journal of Educational Administration and Policy Studies, 8(2), 9-16. DOI: 5897/IJEAPS2015.0435 Msuya, O. W. (2016). Exploring levels of job satisfaction among teachers in public secondary schools in Tanzania. International Journal of Educational Administration and Policy Studies, 8(2), 9-16. DOI: 5897/IJEAPS2015.0435

Muguongo, M. M., Muguna, A. T., \& Muriithi, D. K. (2015). Effects of compensation on job satisfaction among secondary school teachers in Maara Sub-County of Tharaka Nithi County, Kenya. Journal of Human Resource Management, 3(6), 47.

Nadim, M., Chaudhry, M. S., Kalyar, M. N. \& Riaz, T. (2012). Effects of motivational Agboola, 
BolapejuM and Offong, Diana Emmanuel 277 factors on teachers' job satisfaction: A study on public sector degree Colleges of Punjab, Pakistan. The Journal of Commerce, $4(4), 25-32$.

Prakasch, J. N., \& Ghayas, M. M. (2019). Impact of Servant Leadership on Turnover Intentions in Banking Sector of Karachi. RADS Journal of Business Management, 1(1), 22-30.

Rinke, C. R. (2007). Understanding teachers' careers: Linking professional life to professional path. Educational Research $\quad$ Review, 3(1), 1-13. https://doi.org/10.1016/j.edurev.2007.10.001

Rose, J. M., Brink, A. G., \& Norman, C. S. (2018). The effects of compensation structures and monetary rewards on managers' decisions to blow the whistle. Journal of Business Ethics, 150(3), 853-862.

Sharma, J., \& Dhar, R. L. (2016). Factors influencing job performance of nursing staff: mediating role of affective commitment. Personnel Review, 45(1), 161-182.

Shi, Y. X. L., \& Sicular, T. (2010). Are the High Salaries of Employees in Monopoly Industries Justified? [J]. Social Sciences in China, 3.

Silva, N., Travassos, B., Gonçalves, B., Brito, J., \& Abade, E. (2020). Pre-match warm-up dynamics and workload in elite futsal. Frontiers in Psychology, 11.

Smith, A. R., Lawver, R. G., \& Foster, D. D. (2019). National agricultural education supplies $\&$ demand study, 2018 executive summary. http://aaaeonline.org/Teacher-Supply-and-Demand

Sorensen, T. J. (2015). Agriculture teachers' work and family domain characteristics, workfamily conflict, and turnover intentions: A national study (Unpublished doctoral dissertation). Oregon State University, Corvallis.

Tehseen, S., \& Hadi, N. U. (2015). Factors influencing teachers' performance and retention. Mediterranean Journal of Social Sciences, 6(1), 233.

Tulenan, S. (2015). The Effect of Work Environment and Compensation Toward Employee Performance at The Office of State Assets and Auction Service Manado. Jurnal EMBA: Jurnal Riset Ekonomi, Manajemen, Bisnis dan Akuntansi, 3(3).

Van Acker, B. B., Parmentier, D. D., Vlerick, P., \& Saldien, J. (2018). Understanding mental workload: from a clarifying concept analysis toward an implementable framework. Cognition, technology \& work, 20(3), 351-365.

Warm, J. S., Matthews, G., \& Finomore Jr, V. S. (2018). Vigilance, workload, and stress. In Performance under stress (pp. 131-158). CRC Press.

Webb, A. W. (2018). Relational-Cultural Theory and Teacher Retention: A Case Study of Relationships and Resilience in Secondary Mathematics and Science Teachers. Journal of Educational Research \& Practice, 8(1).

Williams, C. C., \& Horodnic, I. A. (2017). Evaluating the illegal employer practice of underreporting employees' salaries. British Journal of Industrial Relations, 55(1), 83111. 